\title{
The Usability of Infographics within the Framework of Learning Outcomes Containing Socioscientific Issues
}

Fatih Aydin ${ }^{1}$

\section{Type/Tür:}

Research/Araştırma

Received/Geliş Tarihi:

September 12/ 12 Eylül 2018

Accepted/Kabul Tarihi:

December 19/ 19 Aralık 2018

Page numbers/Sayfa No: $154-171$

Corresponding

Author/İletişimden Sorumlu

Yazar: fatihaydin14@gmail.com

\section{$\checkmark$ iThenticate}

This paper was checked for plagiarism using iThenticate during the preview process and before publication. / Bu çalışma ön inceleme sürecinde ve yayımlanmadan önce iThenticate yazılımı ile taranmıştır.

Copyright (C) 2019 by

Cumhuriyet University, Faculty of Education. All rights reserved.
Pelin Aksüt ${ }^{2}$

Naciye Somuncu Demir ${ }^{3}$

\begin{abstract}
The aim of this study is to examine the views of $4^{\text {th }}$-grade preservice science teachers $(\mathrm{N}=53)$ on the usability of infographics within the framework of learning outcomes that are included in the 2017 Science curriculum (3-8 grade) and that contain socio-scientific issues. In the study, case study and document analysis were used. The study was carried out within the scope of the Instructional Technologies and Material Development Course by researchers in the fall term of the 2017 - 2018 academic year. The processes of material development and material preparation (posters, banners, etc.) were taught for the first 7 weeks and a midterm exam was conducted afterwards. As a result of this exam, material development knowledge of participants was found to be at a high level and then material preparation processes (5 weeks) were carried out. A form consisting of 5 structured questions prepared by the researchers was used to gather data. Inductive analysis technique was used on the data collected. Results indicate that they are involved in such an application and program for the first time. In addition to that it is possible to say that the inclusion of particularly striking visual elements (icons, graphics, photos, etc.) contributes significantly to the usability of infographics. One of the most important results is that it is particularly emphasized by them in order to raise awareness of issues such as health and country benefits with the using infographics.
\end{abstract}

Keywords: Educational technology, infographic, pre-service science teacher, socioscientific issues, teacher education.

\section{Suggested APA Citation/Önerilen APA Atıf Biçimi:}

Aydın, F., Aksüt, P., \& Somuncu Demir, N. (2019). The usability of infographics within the framework of learning outcomes containing socioscientific issues. Cumhuriyet International Journal of Education, 8(1), 154-171. http://dx.doi.org/10.30703/cije.459384

\footnotetext{
${ }^{1}$ Doçent Doktor, Bolu Abant İzzet Baysal Üniversitesi, Eğitim Fakültesi, Matematik ve Fen Bilimleri Eğitimi Bölümü, Bolu/Türkiye

Associate Professor Doctor, Bolu Abant İzzet Baysal University, Faculty of Education, Department of Mathematics and Science Education, Bolu/Turkey

e-mail: fatihaydin14@gmail.com ORCID ID: http:/ / orcid.org/0000-0003-0453-5734

2 Doktor Öğretim Üyesi, Bolu Abant İzzet Baysal Üniversitesi, Eğitim Fakültesi, Temel Eğitim Bölümü, Bolu/Türkiye Assistant Professor, Bolu Abant İzzet Baysal University, Faculty of Education, Department of Elementary and Early Childhood Education, Bolu/Turkey

e-mail: aksutpelin@gmail.com ORCID ID: https:// orcid.org/0000-0003-0094-5672

${ }^{3}$ Doktor, Bolu Abant İzzet Baysal Üniversitesi, Eğitim Fakültesi, Matematik ve Fen Bilimleri Eğitimi Bölümü, Bolu/Türkiye Doctor, Bolu Abant İzzet Baysal University, Faculty of Education, Department of Mathematics and Science Education, Bolu/Turkey

e-mail: ncsomuncu@gmail.com ORCID ID: https:/ / orcid.org/0000-0001-9325-3987
} 


\title{
Sosyobilimsel Konuları İçeren Kazanımlar Çerçevesinde İnfografiklerin Kullanılabilirliği
}

\begin{abstract}
Öz
Bu çalışmanın amacı 4. sınıfa devam eden fen bilgisi öğretmen adaylarının (N=53) 2017 Fen Bilimleri dersi öğretim programı (3.-8. Sınıf) içerisinde yer alan ve sosyobilimsel konuları içeren kazanımlar çerçevesinde infografiklerin kullanılabilirliğine yönelik görüşlerini incelemektir. Bu çalışmada durum çalışması ve doküman analizi kullanıldı. Bu çalışma 2017 - 2018 akademik yılı güz dönemi içerisinde Öğretim Teknolojileri ve Materyal Geliştirme Dersi kapsamında araştırmacılar tarafından yürütüldü. Çalışmada ilk 7 hafta için öncelikle materyal geliştirme ve materyal hazırlama (poster, afiş, vb.) süreçleri öğretildi ve daha sonra bir ara sınav yapıldı. Bu yapılan ara sınavın sonuçlarına göre fen bilgisi öğretmen adaylarının materyal geliştirmeye yönelik bilgilerinin yüksek seviyede olduğu görüldü ve bundan dolayı daha sonrasında materyal hazırlama süreçleri (5 hafta) gerçekleştirildi. Veri toplamak için araştırmacılar tarafından hazırlanan ve 5 tam yapılandırılmış sorudan oluşan bir form kullanıldı. Sonuçlar bize fen bilgisi öğretmen adaylarının böyle bir uygulama ve program içerisinde ilk kez yer aldığını göstermektedir. Sonuçlara ilişkin, özellikle çarpıcı görsel unsurların (simgeler, grafikler, fotoğraflar vb.) infografikler içerisine dâhil edilmesinin o infografiklerin kullanılabilirliğine önemli ölçüde katkıda bulunduğunu açıkça söylemek mümkündür. $\mathrm{Bu}$ çalışmada dikkati çeken en önemli sonuçlardan bir diğeri ise fen bilgisi öğretmen adayları tarafından infografiklerin kullanımı ile özellikle sağlık ve ülke yararı gibi konuların farkındalığının oluşturulabileceğinin vurgulanmasıdır.
\end{abstract}

Anahtar Kelimeler: Eğitim teknolojisi, fen bilgisi öğretmen adayı, infografik, öğretmen eğitimi, sosyobilimsel konular

\section{Introduction}

Nowadays, scientific and technological developments have affected structure and functions in the field of education as well as causing change in every area of society. The improvement and growth of information technology required new approaches used in education for students and teachers (Ozdamll, Kocakoyun, Sahin and Akdag, 2016). There are various ways of presenting information, allowing information to be presented in a logical order by charts, tables, maps, diagrams and lists so on (TuranGüntepe and Dönmez-Usta, 2017), and one of them is infographics. Infographic which used these components together and include different visual forms of information have gained a place among new learning trends (Yıldırım, Yıldırım, Çelik and Aydın, 2014). Visualization of information is a method that allows it to become more visible and create meaning in student's mind. Thus, student can configure, organize and edit information in this process. Also Ozdaml et al. (2016) stated that the main purpose is not only to give a graphical map of data but also to ensure the actual knowledge, to keep in mind or make it more easily remembered.

Infographic has a curial role in data organizing and therefore it helps people to easily understand a content for instance and is outstanding among the text, the infographic is used an effective tool (Meeusah and Tangkijviwat, 2013). Especially in the long text, major figures and major numerical data may be unnoticed. Therefore, infographic can be defined as an extremely useful material to transfer complex or high amounts of information (Ozdaml et al. 2016). And Davidson (2014) claims that the basic criteria to be considered for preparing a good infographic are as follows:

1. A good infographic tells a story or presents a position. 
2. The title of the infographic stands out and fits the contents and message.

3. The text can be read easily and contrast with the background.

4. Images are clear, relevant, and original or copyright free, and credited.

5. Fonts, shapes, and colours are consistent throughout.

In the literature, infographic is defined as information architecture or information graphics (Ozdaml et al. 2016). The infographics prepared by considering these criteria provide the organization of information and give the opportunity for the formation of the correct schemes, graphics and tables in the minds of the individuals. And an infographic looks fun, but it takes effort. The students will have to do some research and collect the data while presenting their own views along with their infographic. Moreover, using educational infographics provide an opportunity for both teacher and student to make sense of information. Also the infographic can be interpreting conversational topics, visual presentation of data, engaging students in arguments from evidence, constructing explanations and designing solutions.

With the educational perspective, students ensure that more effective visuals are used by infographics instead of traditional course visuals. They also state that the subject of infographics in general is more understandable and more satisfactory (Yıldırım et al. 2014). Moreover, since infographics are easier to keep in mind, they are much more effective. Ozdaml et al. (2016) has revealed that the presentation with infographics can be used in many other courses. By this research, it can be claimed that infographics are not only more effective but also more permanent in the minds. However, the aim of the study that was conducted by Hamilton et al. (2017) was to develop a video infographic that highlights the dangers of driving through floodwaters and provide safety tips to reduce the risk, and to evaluate its effectiveness in changing the beliefs and intentions of Australian adults toward this risky driving behaviour. Research shows that the infographic may not be effective in changing behaviour.

In the literature, infographics are used commonly in a wide range of areas, sectors and organizations. Infographics are widely used in social media, advertisement, media, newspapers and newscasts (Ozdamli and Ozdal, 2018; Lamb et al. 2014; Smiciklas, 2012). However, there are a few studies focusing on infographic use in education or on an effective design of infographics specifically for educational settings (Davidson, 2014; Meeusah and Tangkijviwat, 2013; Ozdamlı et al., 2016 TuranGüntepe and Dönmez-Usta, 2017; Yıldırım, Yıldırım, Çelik and Aydın, 2014). In particular, Davidson (2014) conclude that infographics (information graphics) successfully engage students in science not only in carrying out the research for classroom projects but also in presenting the results of their projects to their peers. Students have created infographics on recycling coffee packaging, water pollution, and air quality. On the other hand, socioscientific issues (SSI) consist both of scientific and social subjects that include social dilemmas and problems. Also, these issues are complex, open-ended, and mostly controversial and have no certain answer (Sadler, 2004; Sadler and Zeidler, 2005). In general, the current context of SSI focused on global topics such as bio-technology, energy sources and global warming dilemmas in Turkey (Topçu, Muğaloğlu and Güven, 2014). Both in the national and international context, SSI literature also showed that most of the studies (e.g., Evagorou and Osborne, 2013; Kara, 2012; Kolstø, 2001; Topçu, 2010) focused on pre-service teachers' 
understanding or views about SSI. And especially, Topçu, Muğaloğlu and Güven (2014) claimed that teaching and learning of SSI need to be provided both in preservice and in-service teacher education in Turkey. So drawing on previous research, we identified how infographic were designed to highlight the socioscientific issues in science courses. The reason of focusing on socioscientific issues in particular is that these are complex controversial scientific matters (Zeidler, 2014). Teachers have a cruial role as to how SSI is handled in the classroom teaching context. At this point in this study, pre-service science teachers can find the related data and gain some information about which they can construct the infographics. In this manner, the connections can be structured with related SSI learning outcomes in science curriculum and infographics.

In the light of these; it was aimed to investigate the opinions of $4^{\text {th }}$-grade preservice science teachers on the usability of infographics within the framework of acquisitions that are included in the 2017 Science curriculum (3rd-8th grades) and that contain socioscientific subjects.

\section{Method}

The case study, in which researchers seek answers to the questions "why" and "how" within the scope of the qualitative research method, was adopted in this study. In order to ensure that studies are carried out systematically and comprehensively, "a single analysis unit, a holistic multiple case analysis method" were considered to be appropriate for this study in the classification performed by Yin (2003, p. 46). While pre-service teachers were classified as a single analysis unit in this study, the determination of the diversity of emphasis on infographics, advantages, disadvantages, limitations, and attitudes were considered as a holistic multiple case analysis. Furthermore, the document analysis was performed on the data obtained (Patton, 2002). The document analysis is a systematic procedure for reviewing or evaluating both printed and electronic documents. Like other analytical methods used in qualitative research, the document analysis requires investigating and interpreting data in order to give meaning, gain understanding and improve empirical knowledge (Corbin \& Strauss, 2008). This repetitive process combines the elements of the content analysis and thematic analysis. The content analysis is the process in which information is organized in the form of categories related to the main questions of the research (Corbin \& Strauss, 2008). The thematic analysis is a form that emerges in data, and the emerging themes become the categories of analysis (Fereday \& MuirCochrane, 2006).

\section{Participants}

The participants of the study consist of a total of 53 fourth-grade students studying at the Department of Science Teaching at the Faculty of Education of a state university, located in the Western Black Sea Region in the fall semester of the 2017-2018 academic year. The criterion sampling method (Patton, 2002) was preferred among purposeful sampling methods in the selection of pre-service teachers who were included in the study. Therefore, the facts that the participants had not received any training on infographics and had not performed any practice before, in addition to not having taken the Teaching Technologies and Material Course in the undergraduate curriculum on the education material developing process were determined as the 
criteria. The participants took the courses on the teaching of socioscientific issues and the 2017 Science Teaching Curriculum.

\section{Data Collection Tool}

A form consisting of 5 questions structured by the researchers was used in the study in order to determine the opinions of the participants. The developed form was discussed by a group of three science educators for its content validity, and the form was finalized in line with their suggestions. The final form contains 5 structured questions on the infographic use of the participants. These are;

$1^{\text {st }}$ question: what did you emphasize on your infographics when you used gathered data to the related learning outcomes for infographics? Why, explain?

$2^{\text {nd }}$ question: Were there any fields/points you wanted to emphasize but you did not add?

$3^{\text {rd }}$ question: What are the advantages, disadvantages, and limitations of infographics within the framework of learning outcomes that contain socioscientific issues?

$4^{\text {th }}$ question: What are your views about using infographic for the related learning outcomes?

$5^{\text {th }}$ question: What is your attitude (expectations, feelings etc.) in the process of preparing infographic?

\section{Process}

The study was carried out within the scope of the Instructional Technologies and Material Development Course in the fall term of the 2017-2018 academic year. In the study, the processes of material development and material preparation (posters, banners, etc.) were taught for the first 7 weeks and a midterm exam was conducted afterwards. As a result of this exam, material development competencies were found to be high, and the necessary criteria were provided for the second stage. Throughout a two-week period, infographic variables, various infographic programs were introduced and taught theoretically. This was followed by a 3-week practice stage, and the practical infographic development process was performed in accordance with the feedback and support of the instructor based on the program, and the content was entirely student-based. In the implementation process, a program with a demo version in the Web environment was used, and the cross usage of different programs was examined. In the final week, the implementation of the written interview form was performed, and the research was terminated. Some of the infographics prepared by participants can be found in the appendix.

\section{Data Analysis}

The inductive analysis technique was applied to the data collected in the study. Inductive analysis (Patton, 2002), which is the process of identifying, coding, and classifying the data, is an analysis method that requires revealing previously unclear themes and dimensions and analysing the data deeply by allowing access to concepts and relations (Yıldırım \& Şimşek, 2006). Within the scope of inductive analysis, page and line numbers were assigned to the form of each participant, then the related sentences were selected for the sub-purposes, and the coding process was started. The codes were grouped in accordance with their common features, and the themes were created. In the process of interpreting the findings, direct quotations were made from 
the data, and they were expressed using abbreviations such as P1, P2, P3,... by sticking to the sequence in the data analysis for the participant group. In order to ensure the reliability of the study, expressions present in the forms were examined by three researchers who are experts in the field of science teaching, and the necessary adding and removing were performed by determining the items with "consensus" and "dissensus." In terms of revealing the credibility and consistency of the coding, the percentages of consistency between the coding performed by different researchers and formulated by Miles and Huberman (1994) were calculated. This consistency percentage ratio should be $70 \%$ and above. In this study, the consistency of the coding between the researchers was calculated as $96 \%$, and the study was considered reliable.

\section{Findings}

Upon analysing the data obtained from the participants, it is observed that the participants tried to create infographics by emphasizing various points when creating infographics within the framework of the first and second questions in the data collection tool (See: Table 1). These types of emphasis of the participants appear as an indicator of what can be emphasized during the infographic preparation process. Accordingly, upon examining Table 1, it can be said that especially the subjects with "sufficiently accessible data," "offering the possibility of proportioning and comparing" and "having (attractive) visuals" have significant potential in terms of infographics creation.

Table 1

The Points That the Participants Tried to Emphasize in The Process of Creating Infographics

\begin{tabular}{|c|c|c|}
\hline Types of Emphasis & $f$ & Participants \\
\hline accessing data sufficiently & 24 & $\begin{array}{l}\text { P3, P7, P10, P11, P12, P13, P20, P24, P25, P26, P27, P29, } \\
\text { P31, P32, P34, P35, P38, P40, P41, P45, P46, P51, P52, P53 }\end{array}$ \\
\hline proportioning and comparing & 22 & $\begin{array}{l}\text { P4, P6, P10, P11, P13, P14, P15, P19, P21, P22, P24, P25, } \\
\text { P29, P30, P31, P32, P34, P39, P41, P47, P49, P52, }\end{array}$ \\
\hline attractive visuals & 17 & $\begin{array}{l}\text { P7, P8, P9, P10, P11, P15, P23, P27, P33, P35, P36, P42, P43, } \\
\text { P45, P46, P50, P51 }\end{array}$ \\
\hline $\begin{array}{l}\text { elements on which detailed } \\
\text { numerical/statistical data }\end{array}$ & 7 & P8, P12, P16, P33, P36, P38, P52, \\
\hline $\begin{array}{l}\text { containing explanatory and } \\
\text { remarkable expressions }\end{array}$ & 7 & P11, P20, P23, P28, P32, P35, P39, \\
\hline $\begin{array}{l}\text { presenting by simplifying without } \\
\text { being complex }\end{array}$ & 7 & P1, P5, P35, P39, P40, P50, P51 \\
\hline providing suggestions & 4 & P7, P12, P46, P51, \\
\hline $\begin{array}{l}\text { being sure of the accuracy of } \\
\text { numerical data }\end{array}$ & 5 & P23, P29, P41, P46, P52, \\
\hline $\begin{array}{l}\text { exampling of positive/negative } \\
\text { situations }\end{array}$ & 5 & P4, P19, P42, P44, P51 \\
\hline
\end{tabular}

Certain examples that can reflect the views of all the participants on this subject are presented below.

I tried to do it in a way that contains fewer visuals and does not strain the eyes. It is less interesting for me when it is complicated. (P1) 
I think that I have remained incapable of taking precautions that can be taken to ensure a healthy adolescence period. I could not obtain enough data on this subject. (P3)

I wanted to compare the electric bill. This comparison showed the data pre- and post-savings. (P4)

I could not find data strong enough to create a graph. (P7)

I wanted to arrange the content mainly with visuals. (P9)

I wanted to emphasize the cost comparison more. (P13)

I paid attention to transmitting statistical data in an interesting way. (P16)

I also wanted to emphasize most that technology in this context is both beneficial and harmful to us. (P19)

I tried to use data that I think are more interesting and that it takes a longer time to forget. (P20)

I compared Turkey both within itself and with China. I wanted to compare it not only with China but also with the countries all around the world. (P21)

...nevertheless, I did not think that it was right to use numerical data in my infographics since I could not be sure of their accuracy. (P23)

I emphasized the rates of stove and natural gas poisoning in Turkey and around the world by months and years. (P25)

I tried to emphasize the subtitles in my acquisition through pictures. (P27)

....but I did not include explicit data, of which accuracy is proved since it they do not exist. (P29)

I used the information above the standards when using the data. (P33)

I could not emphasize packaged foods because there were no attractive visuals. (P35)

I tried to show the importance of biodiversity and behaviors that negatively affect biodiversity. (P42)

I preferred to add the things that can be done to eliminate the problem in this achievement at the end of the infographics. (P46)

I simplified them as much as possible. I did not add the parts that I could not simplify to the infographics. (P50)

However, it draws attention that there are elements to raise awareness among the participants' types of emphasis (See. Table 2). The participants are observed to pay attention if there are significant data on the impacts on humans or for the country.

Table 2

Other Points That the Participants Tried to Emphasize During the Process of Creating Infographics

\begin{tabular}{lcc}
\hline Types of emphasis (in terms of awareness) & $f$ & Participants \\
\hline Containing data on human health & 10 & P10, P33, P34, P41, P18, P25,P29,P30,P47,P48 \\
Containing data on one's country & 9 & P5, P9, P11, P12, P22, P24, P31, P45,P \\
\hline
\end{tabular}

Certain examples that can reflect the views of all the participants on this subject are presented below. 
I wanted to raise awareness of this because waste control by people is important for the country's economy and development. (P5)

I wanted to emphasize the projects that are carried out and planned to be carried out in our country. (P9)

I allocated more space and laid more emphasis on disasters that are more frequent in our country. (P24)

While bringing recycling resources to the forefront, I emphasized studies on the reuse of water after it becomes a waste because water is of great importance for our lives. (P33)

The views of 2 participants attract attention in the process of creating infographics. The views of the participants are as follows.

I presented some data as a plain text since I could not understand how to apply the data I obtained to graphs. (P8)

The graphs did not look exactly as I wanted. I could not set the number ranges by myself. (P34)

This finding creates a perception that these participants expressed their views in this way because they could not fulfil the skill of creating graphs completely. Another finding is the views of the participants on the usability of infographics within the educational process. The fact that the participants are 4 th-grade pre-service science teachers and therefore have sufficient knowledge in this respect provide important findings in terms of infographics. In this context, the findings are presented in terms of the advantages, disadvantages, and limitations as it is asked in the data collection tool. Accordingly, when the findings are examined in terms of the advantages, it can be shown among the most important advantages that infographics increase interest in the subject and they are attention-grabbing, provide a holistic point-of-view (summarizing) and allow for visualization in mind and ensure permanence.

Table 3

The Advantages of Infographics for the Teaching of Learning Outcomes

\begin{tabular}{|c|c|c|}
\hline Advantages of infographics & $f$ & Participants \\
\hline $\begin{array}{l}\text { The fact that they increases interest in the subject } \\
\text { and attract attention }\end{array}$ & 26 & $\begin{array}{l}\text { P1, P4, P5, P6, P7, P9, P12, P14, P16, P19, } \\
\text { P23, P25, P27, P28, P32, P34, P35, P36, P39, } \\
\text { P41, P44, P45, P46, P47, P48, P51, }\end{array}$ \\
\hline $\begin{array}{l}\text { The fact that the subject can be summarized and } \\
\text { they provide holistic reviewability }\end{array}$ & 16 & $\begin{array}{l}\text { P5,P8, P11, P12, P17, P19, P21, P23, P27, } \\
\text { P29, P30, P32, P36, P38, P41, P46, }\end{array}$ \\
\hline $\begin{array}{l}\text { The fact that they ensures envisioning and } \\
\text { permanence }\end{array}$ & 16 & $\begin{array}{l}\text { P2, P5, P7, P6, P8, P10, P15, P26, P29, P33, } \\
\text { P34, P36, P42, P43, P52, P53, }\end{array}$ \\
\hline $\begin{array}{l}\text { The fact that they ensure visualization and } \\
\text { facilitates comprehending/ understanding }\end{array}$ & 13 & $\begin{array}{l}\text { P3, P5, P7, P9, P13, P14, P15, P18, P20, P24, } \\
\text { P30, P35, P36, }\end{array}$ \\
\hline The fact that they facilitate presentation & 2 & P45, P51, \\
\hline The fact that they increase credibility/ sensitivity & 4 & P4, P9, P26, P37, \\
\hline $\begin{array}{l}\text { The fact that they provide creativity/a different } \\
\text { point-of-view }\end{array}$ & 3 & P22, P31, P51, \\
\hline $\begin{array}{l}\text { The fact that they are effective in developing the } \\
\text { Scientific Process Skills (SPS) (analysis, synthesis, } \\
\text { data collection, research, etc.) }\end{array}$ & 3 & P26, P31, P52 \\
\hline $\begin{array}{l}\text { The fact that they provide an enjoyable learning } \\
\text { environment }\end{array}$ & 2 & P10, P22 \\
\hline The fact that it can be used for any age group & 1 & P41 \\
\hline
\end{tabular}


Certain examples that can reflect the views of all the participants on this subject are presented below.

Therefore, we can draw more attention to socioscientific issues and inform people about them. (P1)

Numerical data and graphs make the event that is desired to be explained more convincing and concrete. (P4)

It is advantageous in terms of permanence and interest since visual elements are included more. (P6)

The fact that it is visual and becomes more comprehensible with graphs.

(P9)

Many topics can be observed with all the data, important points, and all the statistics together. (P11)

I may have learned something by having fun and difficulty at the same time. (P10)

I think that permanence will also be high if design elements are considered. (P15)

It is easy to keep in mind because it gives a summary of all the information as a whole and attracts the attention of people. (P19)

It increases creativity and different perspectives. (P22)

It increases thinking skills such as analysis and synthesis. It ensures permanence based on the cause and effect relationship. (P26)

It can appeal to any age. It is not hard to understand. (P41)

The fact that it can be easily explained, and the desired signs, symbols and pictures can be used are some of the positive aspects. (P45)

It enables us to make comments on the study with scientific data. (P52)

Upon examining the findings in terms of the disadvantages (Table 4), it is draw attention that infographics require a troublesome and time-consuming process, it is difficult to access the (real) data, and it is not possible to create a detailed presentation.

Table 4

The Disadvantages of Infographics for Teaching the Learning Outcomes

\begin{tabular}{lcl}
\hline Disadvantages of infographics & $f$ & \multicolumn{1}{c}{ Participants } \\
\hline $\begin{array}{l}\text { The fact that graphitizing and making sense of it are } \\
\text { troublesome and time-consuming }\end{array}$ & $13 \begin{array}{l}\text { P1, P5, P6, P7, P12, P23, P26, P29, P36, } \\
\text { P40, P42, P43, P49, }\end{array}$ \\
$\begin{array}{l}\text { The fact that it is difficult to achieve (valid) data } \\
\text { The fact that it is hard to define the presentation } \\
\begin{array}{l}\text { content in comprehensive subjects } \\
\text { The fact that it requires updating the data }\end{array}\end{array}$ & $\begin{array}{l}\text { P13, P18, P21, P23, P26, P29, P30, P31, } \\
\text { P32, P40, P50, }\end{array}$ \\
\hline
\end{tabular}

Certain examples that can reflect the views of all the participants on this subject are presented below.

Making sense of complex infographics can take a lot of time. (P5)

When the subject area is wide, there can be confusion as to what should be added to the graph and what should not be added. (P10)

It is a time-consuming and tiresome process to set up the order without confusion. (P12) 
The subject can be misunderstood if it is realized without considering the accuracy or inaccuracy of the data used. (P18)

It is a material that needs to be updated continuously. The data used in the graph may change over time. (P27)

If students do not know how to read a graph, it may not contribute to them from any aspect. (P31)

We can present the subject as a superficial summary rather than in a detailed way. (P39)

Upon examining the findings in terms of the limitations (Table 5), 3 important factors emerge. It is possible to consider them as limitations that originate from the program (infrastructure, accessibility, etc.), the subject (the fact that it is multidimensional such as socioscientific subjects), and the individual (age group and the ability to interpret a graph).

Table 5.

The Limitations of Infographics for Teaching the Learning Outcomes

\begin{tabular}{|c|c|c|}
\hline Limitations of infographics & $f$ & Participants \\
\hline $\begin{array}{l}\text { The detailed presentation of the subject (in } \\
\text { socioscientific terms) }\end{array}$ & 13 & $\begin{array}{l}\text { P2, P3, P5, P11, P12, P19, P20, P28, P30, P34, P38, } \\
\text { P50, P52 }\end{array}$ \\
\hline The features of the relevant program & 7 & P8, P9, P11, P12, P17, P47, P48 \\
\hline $\begin{array}{l}\text { The suitability of the data content for a } \\
\text { student's level }\end{array}$ & 3 & P1,P12, P33 \\
\hline The formal structure of infographics & 3 & P6, P27, P35 \\
\hline
\end{tabular}

Certain examples that can reflect the views of all the participants on this subject are presented below.

Since socioscientific issues are open to debate, it can lead to conflicts between people with opposite opinions. Therefore, objective infographics can be prepared. (P2)

One may not go into the exact details of a subject, or it can take time to make sense of complex infographics. (P5)

It should be possible to amend the graphs and copy them to text boxes. (P11)

The subject cannot be explained fully. (P16)

It is easy to use when used on the Internet, but it is difficult to use when it is printed out because it is difficult to use infographics when they are too long. (P27)

The fact that we provide more information about a field creates the risk of shifting to other fields. The student's level should be taken into consideration. (P33)

Recent findings on the data obtained by the data collection tool are the attitudes of the participants in this process. It is a known fact that attitude is an important factor in education. Therefore, it is understood that these findings contain important elements for the usability of infographics in education. Accordingly, upon examining Table 6, negative attitudes that originate especially from the infographics preparation program and being performed for the first time attract attention. Nevertheless, the findings also clearly show that the participants experience a shift towards a positive 
attitude at the end of the process, although they exhibit negative attitudes at the beginning of the process.

Table 6

Attitudes of the Participants in The Process of Preparing Infographics

\begin{tabular}{|c|c|c|c|}
\hline & & $\mathrm{f}$ & Participants \\
\hline \multirow{6}{*}{$\begin{array}{l}\text { Elements that cause } \\
\text { negative attitudes } \\
\text { (fear, getting angry, } \\
\text { getting bored, etc.) }\end{array}$} & $\begin{array}{l}\text { Program-based (English, freezing } \\
\text { on the Internet, being paid, etc.) } \\
\text { elements }\end{array}$ & 13 & $\begin{array}{l}\text { P1, P4, P10, P17, P19, P21, } \\
\text { P28, P31, P36, P39, P43, P48, } \\
\text { P51 }\end{array}$ \\
\hline & $\begin{array}{l}\text { Doing it for the first time/being } \\
\text { afraid of not being able to do it }\end{array}$ & 12 & $\begin{array}{l}\text { P2, P6, P13, P16, P24, P25, } \\
\text { P27, P28, P31, P40, P42, P52 }\end{array}$ \\
\hline & $\begin{array}{l}\text { Difficulty in accessing the } \\
\text { data/investigating the subject a lot }\end{array}$ & 10 & $\begin{array}{l}\text { P3, P13, P18, P21, P26, } \\
\text { P29,P34, P35, P37, P39, P49 }\end{array}$ \\
\hline & Spending time to learn the program & 6 & P4, P8, P10, P20, P22, P23 \\
\hline & $\begin{array}{l}\text { The wish/process of preparing } \\
\text { effective infographics }\end{array}$ & 6 & P5, P6, P12, P13, P30, P34 \\
\hline & $\begin{array}{l}\text { The failure to achieve the desired } \\
\text { result }\end{array}$ & 4 & P3, P28, P36, P50, \\
\hline \multirow{5}{*}{$\begin{array}{l}\text { Elements that cause } \\
\text { positive attitudes } \\
\text { (excitement, enjoying, } \\
\text { being pleased, etc.) }\end{array}$} & $\begin{array}{l}\text { Producing different and new } \\
\text { things/doing it for the first time }\end{array}$ & 4 & P20, P22, P33, P37 \\
\hline & $\begin{array}{l}\text { Discovering new things and being } \\
\text { able to do what one wants }\end{array}$ & 3 & P11, P19 \\
\hline & $\begin{array}{l}\text { Collecting the data and transferring } \\
\text { them to the program }\end{array}$ & 2 & P22, P47 \\
\hline & Becoming experienced & 1 & P41, \\
\hline & $\begin{array}{l}\text { Achieving attractiveness (visuality, } \\
\text { etc.) }\end{array}$ & 1 & P10 \\
\hline \multirow[t]{3}{*}{$\begin{array}{l}\text { Elements that cause a } \\
\text { change from negative } \\
\text { to positive }\end{array}$} & $\begin{array}{l}\text { Learning the program } \\
\text { time/gaining experiencing }\end{array}$ & 14 & $\begin{array}{l}\text { P5, P7, P14, P15, P20, P24, } \\
\text { P25, P33, P38, P40, P42, P46, } \\
\text { P49, P51 }\end{array}$ \\
\hline & $\begin{array}{l}\text { Reaching the desired infographics } \\
\text { after a difficult process }\end{array}$ & 12 & $\begin{array}{l}\text { P3, P6, P8, P16, P18, P26, P31, } \\
\text { P35, P43, P44, P48, P53 }\end{array}$ \\
\hline & $\begin{array}{l}\text { Achieving the data after long } \\
\text { research }\end{array}$ & 3 & P13, P32, P46 \\
\hline
\end{tabular}

Certain examples that can reflect the views of all the participants on this subject are presented below.

I have never heard of infographics before. Therefore, I approached this subject in quite a prejudiced manner. (P2)

At first, I had difficulty in using the program, but then I liked it. (P5)

At first, I had a hard time of how to do it. Later, I started to get ahead as

I did it right and I even enjoyed it. (P6)

I tried a lot of times to make a graph and I became very happy when I made it. (P11)

I discovered a lot of new things. It was pleasing to be able to do whatever I wanted without needing anything else. (P12)

It is both a difficult and stressful process to prepare eye-catching infographics that will appeal to the eye as a whole. (P18)

It took a lot of time since I could not find any data. There were times when I could not sleep when placing the data I found. (P19) 
The fact that the programs are in English and very slow also caused difficulty in preparing infographics. (P22)

I had a lot of fun and learned a lot when collecting the data. Then, I had also much fun when transferring these data to the program. (P26)

No matter how much tired I became, I got a satisfactory result, which I believe I will implement in the future. (P31)

I used such an application for the first time. I had sleepless nights. However, I calmed down as I started to prepare the infographics. I became more self-confident as the work continued. (P33)

I had a lot of pleasure when preparing it. Dealing with different things in the university life contributed positively to my personal development. (P35)

Not being able to achieve the desired result made me unhappy. (P36)

I became happy since I revealed a structure, i.e. the infographics, with the graphic program for the first time. (P37)

Infographic was a program that I had used previously. I had much pleasure when preparing it. (P41)

For some time, I thought I would not find any numerical value and became very unhappy. Then, I found the values and thankfully, I completed the infographics. (P46).

\section{Discussion}

In the age of information, infographics have gained importance which offer users complex information in an attractive and aesthetic visual manner (Özdamlı and Özdal, 2018). Materials prepared for learning environments should be designed in a way taking the characteristics of the participants/subjects into consideration (TuranGüntepe and Dönmez-Usta, 2017). In this research, the view of pre-service science teachers on the usability of infographics in the framework of socio scientific issues in science education are examined and the results show that the usability of infographic is quite high. On the contrary, Turan-Güntepe and Dönmez-Usta (2017) researched that the pre-service teachers could not design infographics at sufficient level. As for the disadvantages, it is seen that infographic preparation is usually a laborious and difficult process, and the availability of data is also a reflection of this factor. The results indicate that pre-service science teachers are involved in such an application and program for the first time. For example one of them said "...At first, it was difficult to use the program, but I liked it later... (P5)". In line with this findings, infographic preparation may also be associated with the necessary experience in building information- graphics- infographics and in general, students do not know much about infographics (Özdamlı et al., 2016; Turan-Güntepe and Dönmez-Usta, 2017). Therefore, it can be predicted that the experience of making applications on infographics can help overcome the above mentioned disadvantages. Besides, it is advantageous in terms of permanence and interest because it gives more space to visual materials (icons, graphics, images etc.). This results coincided that the use of visual materials such as graphics, diagrams, figures and tables in teaching materials is important to address more than one sensory organ, facilitating recall, and configure 
the knowledge (Schwier and Misanchuk, 1993; Dönmez Usta, 2016 as cited in TuranGüntepe and Dönmez-Usta, 2017).

Pre-service science teachers stated that "It is easy to keep in mind because it gives all the information in summary as a whole, and it attracts the attention of the person. (P19)", "It is easy to understand that some of the positive aspects of using icons, symbols and pictures are what you want. (P45)" and "Numerical data are more convincing and concrete because of the use of graphics. (P4)". They are in favour of infographics, they could present information in a more organized way and had more advantages in terms of both preparation and presentation, compared to other visual materials such as posters, banners and they can connect with infographics more deeply than they do with text or PowerPoint presentations (Davidson, 2014; Y1ldırım et al., 2014). As for the results, it is possible to say that the inclusion of particularly striking visual materials (icons, graphics, images etc.) contributes significantly to the usability of infographics.

In this research, one of the most important results is particularly emphasized by pre-service science teachers in order to raise awareness of issues such as health and country benefits with the use of infographics. For example; one of them said that "I stressed that stove and natural gas poisoning in Turkey and the World rate by month and year. (P25)" According to that, infographics have an important role in socioscientific issues. This result emerged that infographics may be useful course material to draw attention to and raise awareness of such issues. Also this result concluded with a lot of literature (Davidson, 2014; Hamilton et al. 2018; Özdaml et al. 2016). In this context, course materials for conventional presentations made by Power Point pages method may be abandoned; and instead of it using infographics, a more effective presentations providing more permanent information may be possible. And, Topçu, Muğaloğlu and Güven (2014) claimed that teaching and learning of SSI need to be provided both in pre-service and in-service teacher education. So, it is thought that infographics directed to related topics will constitute a prediction for use in socioscientific issues. Thus, more systematic comparison possibilities can be provided.

\section{Conclusion and Suggestions}

In this study, the views of final grade pre-service science teachers on the usability of infographics within the framework of socioscientific issues included in science education were examined. The findings obtained within this framework clearly show that the usability of infographics is quite high. In other words, the facts that there exist data that can allow creating graphs especially on the subject and that these data can be presented in a proportioned and comparable way are important factors. Nevertheless, these factors may also turn into an element that can cause a negative attitude in the infographics creation process because when the findings on the attitudes of pre-service science teachers are examined, it is understood that the difficulty in reaching data causes negative attitudes. This result indicates that if practices are carried out with infographics, the relevant group should be supported in order to reach the data or practices should be structured within the framework of the accessible data. Nevertheless, it is possible to say that the inclusion of particularly attractive visual elements has made a significant contribution to the usability of infographics.

A significant result emerging from the findings is particularly emphasized by pre-service science teachers in order to raise awareness of issues such as health and country benefits. Therefore, this result suggests that infographics may be usable tools 
to draw attention to and raise awareness of such issues. The fact that final grade preservice science teachers are both receiving education and have the qualifications of a teacher presents important results about the place of infographics in the teaching of learning outcomes containing socioscientific subjects. Upon examining the findings, it is understood that infographics have considerable advantages in this respect. In particular, attracting attention and increasing the interest, the possibility to summarize the subject, visualization of the subject, and ensuring permanence appear as pedagogically significant factors. At the same time, as mentioned in the literature, socioscientific issues include dilemmas. Thanks to the above advantages of infographics, these dilemmas can be revealed more clearly and comparatively. This may facilitate interpretation, too. Moreover, these factors are the subjects that education emphasizes much in terms of the learning and teaching process.

Despite all these advantages, it is also true that there are disadvantages and limitations of infographics. In terms of disadvantages, it is observed that infographics preparation is usually a laborious and difficult process, and the availability of data is also a factor. Nevertheless, upon interpreting these disadvantages by associating them with the attitudes of pre-service science teachers, it is possible to see that pre-service science teachers who usually mention these disadvantages are those who indicate that they are involved in such an application and program for the first time. Therefore, it can be estimated that gaining experience by carrying out practices on infographics can eliminate the above-mentioned disadvantages. Again, the fact that achieving the correct information and making updates are important in terms of not having disadvantages in this respect is also among the results obtained. Upon examining the findings in terms of limitations, it is understood that infographics have limitations originating from the program, individual, and subject.

Especially, the fact that socioscientific issues are multifaceted and contain dilemmas in their context is a significant limitation that attracts attention. This finding leads to the conclusion that socioscientific issues should be carefully structured when being presented as infographics. An important result emerging from the findings in terms of limitations is that the target group must have the ability to interpret graphs in the use of infographics. Therefore, measuring and knowing the skills of the target group in this subject or raising them in terms of graph reading emerge as an important requirement in terms of infographics practices. Finally, upon examining the findings on the attitudes of pre-service science teachers in the infographics preparation process, it is observed that the fact that pre-service science teachers had such an experience regarding both the practice and the relevant technology for the first time led to their developing negative attitudes. This situation is regarded as an expected result because situations of which results we do not see may always create question marks. Despite this, even just a bit, it draws attention that doing something for the first time and creating new things lead to positive attitudes. The most important result with regard to the attitude emerges upon investigating the process because it is understood that the attitudes of pre-service science teachers with negative attitudes at the beginning turn from negative into positive as they gain experience and achieve the desired data and product. This result brings about the necessity of motivating and informing the target group within the framework of this finding before carrying out practices with 
infographics. Therefore, it can be considered that more effective practices can be carried out.

As a result, infographics emerge as a tool that can be effectively used in education. However, when examined holistically, one of the most important elements to consider is that data, graphs, and visuals can provide meaningful and effective results when they are evaluated together with a relational logic. Thus, it is an undeniable fact that infographics must be developed and studied within this framework. It is thought that studies that are especially based on educational technologies and are carried out within the framework of attitudes will make a contribution.

\section{References}

Büyüköztürk, Ş., Çakmak, E. K., Akgün, Ö. E., Karadeniz, Ş., \& Demirel, F. (2017). Bilimsel araştırma yöntemleri. Pegem Atıf İndeksi, 1-360. https:// doi.org/10.14527/9789944919289

Corbin, J., \& Strauss,A. (2008). Basics of qualitative research: Techniques and procedures for developing grounded theory (3rd ed.). Thousand Oaks, CA: Sage. https:// doi.org/10.4135/9781452230153

Davidson, R. (2014). Using infographics in the science classroom. The Science Teacher, 81(3), 34-39. https://doi.org/10.2505/4/tst14_081_03_34

Evagorou, M., \& Osborne, J. (2013). Exploring young students' collaborative argumentation within a socioscientific issue. Journal of Research in Science Teaching, 50(2), 209-23. https:/ / doi.org/10.1002/tea.21076

Fereday, J., \& Muir-Cochrane, E. (2006). Demonstrating rigor using thematic analysis: A hybrid approach of inductive and deductive coding and theme development. International Journal of Qualitative Methods, 5(1), 80-92. https:/ / doi.org/10.1177/160940690600500107

Glesne C. (2006). Becoming qualitative researchers: an introduction (3rd ed.). Boston, MA: Pearson Education.

Gülrenk, K. (2015). Görsel iletişimde bilgi mimarlı̆̆ı ve infografik tasarımlar (Yayınlanmamış Yüksek Lisans Tezi). İstanbul Kemerburgaz Üniversitesi, İstanbul.

Hamilton, K., Peden, A. E., Keech, J. J., \& Hagger, M. S. (2018). Changing people's attitudes and beliefs toward driving through floodwaters: evaluation of a video infographic. Transportation Research Part F: Traffic Psychology and Behaviour, 53, 50-60. https:/ / doi.org/10.1016/j.trf.2017.12.012

Kara, Y. (2012). Pre-service biology teachers' perceptions on the instruction of socioscientific issues in the curriculum. European Journal of Teacher Education, 35(1), 111-129. https://doi.org/10.1080/02619768.2011.633999

Kolstø, S. D. (2001). Scientific literacy for citizenship: Tools for dealing with the science dimension of controversial SSI. Science Education, 85, 291-310. https:// doi.org/10.1002/sce.1011

Lamb, G. R., Polman, J. L., Newman, A., \& Smith, C. G. (2014). Science news infographics: teaching students to gather, interpret, and present information graphically. The Science Teacher, 81, 25-30. https://doi.org/10.2505/4/tst14_081_03_25 
Meeusah, N., \& Tangkijviwat, U. (2013) Effect of data set and hue on a content understanding of infographic. Retrieved from http:/ / www.repository.rmutt.ac.th/xmlui/handle/123456789/1263

Merriam S. B. (2009). Qualitative research: A guide to design and implementation. San Francisco, CA: Jossey-Bass.

Miles, M. B., \& Huberman, A. M. (1994). Qualitative data analysis: An expanded sourcebook. SAGE.

Ozdamli, F., \& Ozdal, H. (2015). Life-long learning competence perceptions of the teachers and abilities in using information-communication technologies. Procedia-Social and Behavioral Sciences, 182, 718-725. https:// doi.org/10.1016/j.sbspro.2015.04.819

Ozdamli, F., Kocakoyun, S., Sahin, T., \& Akdag, S. (2016). Statistical reasoning of impact of infographics on education. Procedia Computer Science, 102, 370-377. https:// doi.org/10.1016/j.procs.2016.09.414

Ozdamli, F., \& Ozdal, H. (2018). Developing an instructional design for the design of infographics and the evaluation of infographic usage in teaching based on teacher and student opinions. Eurasia Journal of Mathematics, Science and Technology Education, 14(4), 1197-1219. https:// doi.org/10.29333/ ejmste/81868

Patton, M. Q. (2002). Qualitative research E evaluation methods. London: SAGE Publication.

Sadler, T. D. (2004). Informal reasoning regarding SSI: A critical review of research. Journal of Research in Science Teaching, 41(5), 513-536. https://doi.org/10.1002/tea.20009

Sadler, T. D., \& Zeidler, D. L. (2005). The significance of content knowledge for informal reasoning regarding SSI: Applying genetics knowledge to genetic engineering issues. Science Education, 89, 71-93. https://doi.org/10.1002/sce.20023

Smiciklas, M. (2012). The power of infographics: Using pictures to communicate and connect with your audiences. Indianapolis, IN: Que.

Terzi, A. R., \& Tezci, E. (2007). Necatibey Eğitim Fakültesi öğrencilerinin öğretmenlik mesleğine ilişkin tutumları. Kuram ve Uygulamada Eğitim Yönetimi, 52, 593-614.

Topçu, M. S. (2010). Development of attitudes towards socioscientific issues scale for undergraduate students. Evaluation and Research in Education, 23(1), 51-67. https:/ / doi.org/10.1080/09500791003628187

Topçu, M. S., Muğaloğlu, E. S., \& Güven, D. (2014). Fen eğitiminde sosyobilimsel konular: Türkiye örneği. Educational Sciences: TheoryEPractice, 14(6), 1-22.

Turan-Güntepe, E. \& Dönmez-Usta, N. (2017). Öğretmen adaylarının geliştirdikleri materyallerin değerlendirilmesi: Etkili bir sınıf yönetimi örneği. Eurasian Journal of Researches in Social and Economics, 4(7), 102-115.

Yıldırım, S., Yıldırım, G., Celik, E., \& Aydin, M. (2014). Bilgi grafiği (infografik) oluşturma sürecine yönelik öğrenci görüşleri. Journal of Research in Education and Teaching, 3(24), 247-255.

Yıldırım, A., \& Şimşek, H. (2006). Sosyal bilimlerde nitel araştırma yöntemleri. Seçkin Yayıncilik.

Yin, R. K. (2003). Case study research: Design and methods. (3rd ed.). Thousand Oaks, CA: Sage. 
Zeidler, D. L. (2014). Socioscientific issues as a curriculum emphasis: theory, research and practice. In N. G. Lederman \& S. K. Abell (Eds.), Handbook of research on science education, Volume II (pp. 697-726). New York: Routledge.

\section{Appendix}

Sample Infographics Prepared by the Participants
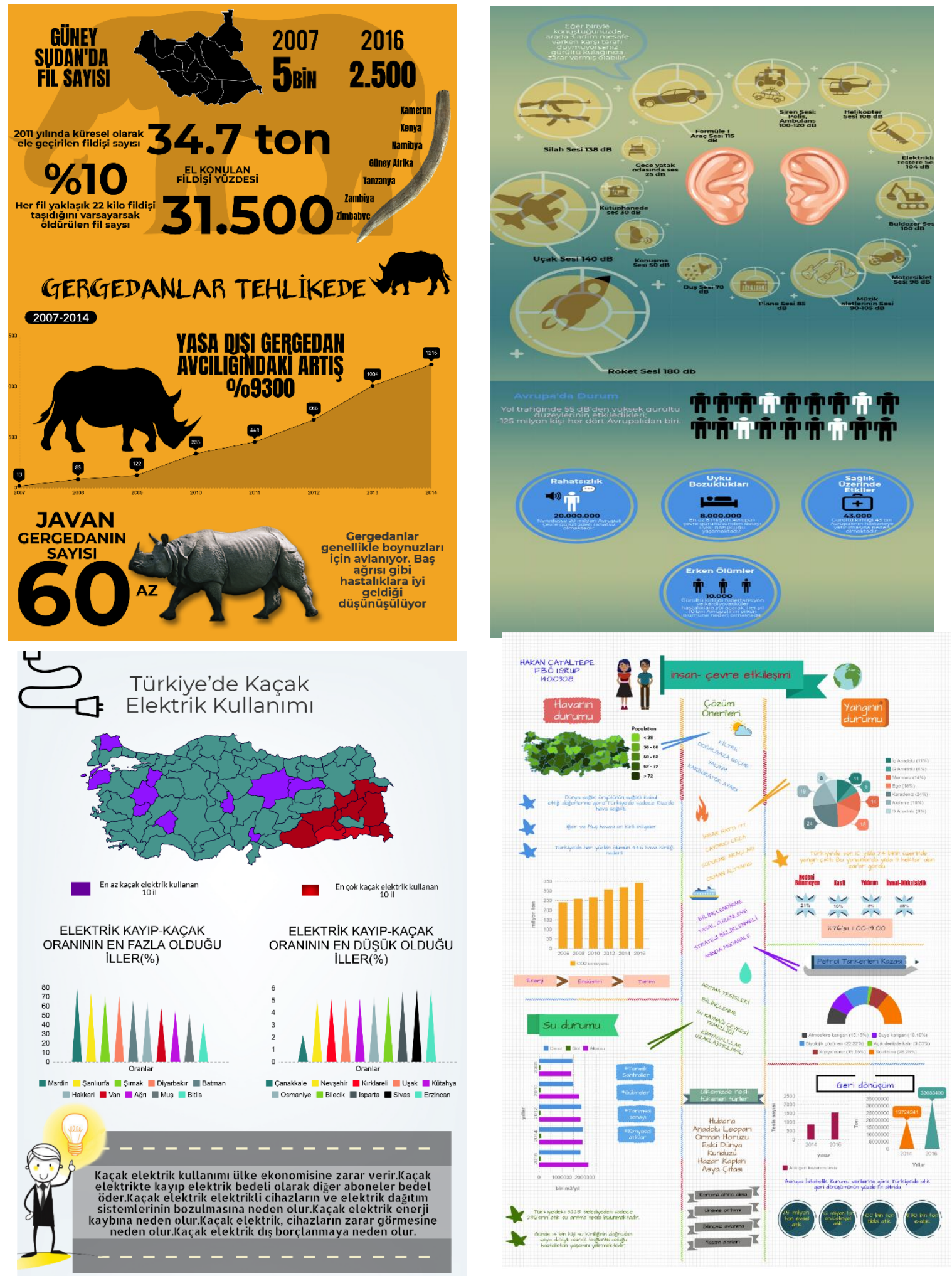


\section{Authors' Biodata / Yazar Bilgileri}

Fatih Aydın is working as a Associate Professor Dr. at Bolu Abant Izzet Baysal University, Education Faculty, Science Education Department. His research interests are history and nature of technology, technology education, alternative assessment and teacher training.

Fatih AYDIN Bolu Abant İzzet Baysal Üniversitesi Eğitim Fakültesi Fen Eğitimi alanında Doçent olarak çalışmaktadır. Çalışma alanları ise teknolojinin tarihi ve doğası, teknoloji eğitimi, alternatif ölçme değerlendirme ve öğretmen eğitimi üzerinedir.

Pelin Aksüt is working in Bolu Abant İzzet Baysal University, Faculty of Education Department of Elementary and Early Childhood Education as assistant professor. She graduated from Bolu Abant Izzet Baysal University Science Education and completed her master degree and $\mathrm{PhD}$ degree at the same university and department. Her research interest are science education in early childhood and environment education in early years.

Pelin AKSÜT Bolu Abant İzzet Baysal Üniversitesi Eğitim Fakültesi Okul Öncesi Öğretmenliği Anabilim dalında doktor öğretim üyesi olarak çalışmaktadır. Lisansını Bolu Abant İzzet Baysal Üniversitesi, Eğitim Fakültesi Fen Bilgisi Öğretmenliğinde yüksek lisans ve doktorasını yine aynı üniversite ve bölümde tamamlamıştır. Okul öncesi dönemde fen eğitimi ve çevre eğitimi alanları üzerinde çalışmalar yapmaktadır.

Naciye Somuncu Demir is research assistant at Science Education Department, Bolu Abant Izzet Baysal University. She received her BA and MA degree at Science Teaching Department of Gazi University. In addition to she received her PhD degree at Science Teaching Department at Bolu Abant Izzet Baysal University. Her research interests are multifuncionalty of agriculture and food-fiber literacy, outdoor learning, garden based education and teacher education.

Naciye SOMUNCU DEMİR Bolu Abant İzzet Baysal Üniversitesi, Eğitim Fakültesi, Matematik ve Fen Bilimleri Eğitimi Bölümünde araştırma görevlisi olarak çalışmaktadır. Lisans ve Yüksek Lisans eğitimini Gazi Üniversitesi Fen Bilimleri Eğitimi Bölümünde tamamlamıştır. Ek olarak doktora eğitimini Bolu Abant İzzet Baysal Üniversitesi Fen Bilimleri Eğitimi Bölümünde tamamlamıştır. Çok fonksiyonlu Tarım Okuryazarlığı, Gıda-Fiber Okuryazarlığı, mekân dışı eğitim, bahçe temelli eğitim ve öğretmen eğitimi üzerine çalışmaktadır. 